\begin{tabular}{|c|c|}
\hline JINAL INSTL & $\begin{array}{l}\text { Volume } 3 \text { Nomor. 1, April } 2018 \\
\text { P-ISSN : 2541-1179, E-ISSN : 2581-1711 } \\
\text { Ojs :http://journal.uin-alauddin.ac.id/index.php/instek/index }\end{array}$ \\
\hline 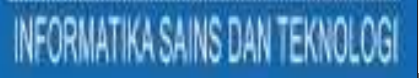 & Email : instek@uin-alauddin.ac.id \\
\hline
\end{tabular}

\title{
Penerapan Algoritma Greedy Untuk Mendeteksi Aktivitas Lansia Pada Karpet Menggunakan Arduino Mega
}

\author{
PUJIANTI WAHYUNINGSIH \\ STMIK Handayani Makassar \\ Alamat: Jl. Adhyaksa Baru No. 1 Makassar. 90231 \\ Email: uji.wahyuningsih@gmail.com
}

\begin{abstract}
Abstrak
Tujuan penelitian ini adalah menerapkan algoritma greedy dalam mendeteksiaktivitas lansia diatas karpet menggunakan Arduino Mega.Pada karpet terdapat node-node sensor yang terhubung ke arduino mega danakan aktif ketika sensor tersebut ditekan. Algoritma greedy pada penelitian ini berfungsi untuk menentukan aktivitas lansia pada saat berdiri, berjalan, duduk dan berbaring. Jika node sensor yang tertekan antara 2 sampai 4 maka lansia sedang berdiri atau berjalan, jika 5 sampai 8 node sensor tertekan maka lansia sedang duduk dan jika yang tertekan lebih dari 9 node maka lansia sedang berbaring. Karpet pada penelitian berukuran $120 \times 240 \mathrm{~cm}$ dengan jumlah node sensor sebanyak 30 titik. Hasil dari penelitian ini adalah algoritma greedy dapat menentukan aktivitas lansia saat berdiri, berjalan, duduk dan berbaring.
\end{abstract}

\section{Kata Kunci : Algoritma greedy, karpet,lansia,node sensor.}

\section{I.Pendahuluan}

Karpet merupakan media alas yang banyak digunakan dirumah bahkan dimana saja yang berfungsi sebagai alas lantai, bahkan karpet sudah menjadi kebutuhan pokok yang sering digunakan dalam suatu rumah. Terdapat banyak aktivitas yang dapat dilakukan diatas karpet, seperti berjalan, berdiri, duduk dan berbaring. Dalam sebuah rumah terdapat anggota keluarga yang sering beraktivitas diatas karpet, seperti anak-anak, remaja, orang tua dan lansia.

Penggunaan karpet untuk melindungi lansia dari sentuhan lantai akan sangat bermanfaat bagi anggota keluarga atau penjaga lansia yang sedang beraktifitas diluar rumah karena hampir keseluruhan aktivitas lansia dilakukan diatas karpet.Lansia (Lanjut Usia) merupakan tahapan dimana manusia sudah mencapai 


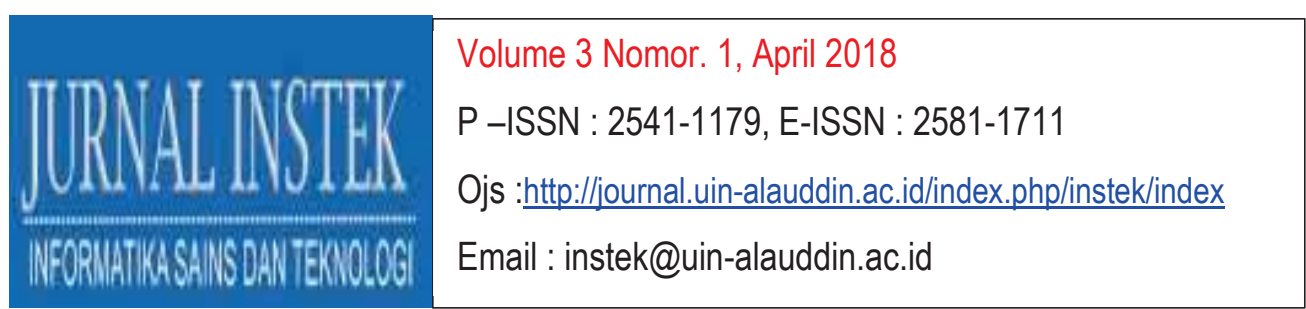

fase umur penuaan. Secara biologis dan fisik hampir semua Lansia mempunyai daya tahan tubuh yang kurang serta sudah tidak banyak beraktifitas lagi, sehingga kegiatan kesehariannya hanya dilakukan di sekitar rumah atau bahkan hanya didalam rumah saja.

Dalam kehidupan sehari-hari lansia harus selalu dijaga oleh keluarga atau penjaga lansia. Namun tingginya aktivitas penjaga lansia membuat mereka selalu merasa was-was dan khawatir jika meninggalkan lansia sendiri dirumah atau dalam ruangan.Olehnya itu untuk mengetahui aktivitas lansia dari jarak jauh diperlukan sebuah karpet yang terhubung ke Arduino mega dan terkoneksi ke jaringan. Untuk menentukan aktivitas lansia saat berdiri, berjalan, duduk dan berbaring, penulis menggunakanalgoritma greedy sebagai sistem pengambil keputusannya.

\section{Metode Penelitian}

\section{a. Algoritma Greedy}

Pada penelitian sebelumnya telah dibahas tentang Rancang Bangun Sistem Deteksi Aktivitas Lansia Berbasis Arduino Mega[1]. Penelitian tersebut menjelaskan secara singkat penggunaan algoritma greedy untuk mendeteksi aktivitas lansia diatas karpet. Namun dalam penelitian ini akan dijelaskan secara menyeluruh tentang bagaimana pengaplikasian dan penerapan algoritma greedy untuk pengambil keputusan aktivitas lansia apakah sedang berdiri, berjalan atau berbaring serta penjelasan node sensor pada karpet yang digunakan.

Alasan mengapa peneliti menggunakan algoritma greedy adalah karena algoritma ini bersifat rakus dan mengambil keputusan berdasarkan titik terdekat yang ada pada node sekitarnya, namun tidak memperhatikan jarak dari node-node tersebut. Beberepa penelitian telah mengaplikasikan algoritma greedy seperti untuk pengambilan keputusan pada saat akan menukar uang rupiah. Pada penelitian tersebut dijelaskan bahwa terdapat banyak kondisi pilihan yang harus dipilih untuk menukar uang rupiah tanpa harus memparhatikan titik langkah dari sistem dengan mengambil keputusan yang terbaik . 
Volume 3 Nomor. 1, April 2018

P-ISSN : 2541-1179, E-ISSN : 2581-1711

Ojs :http://journal.uin-alauddin.ac.id/index.php/instek/index

Email : instek@uin-alauddin.ac.id

\section{b. Lanjut Usia (LANSIA)}

Lansia (Lanjut Usia) merupakan tahapan dimana manusia sudah mencapai fase umur penuaan. Secara biologis dan fisik hampir semua Lansia mempunyai daya tahan tubuh yang kurang serta sudah tidak banyak beraktifitas lagi, sehingga kegiatan kesehariannya hanya dilakukan di sekitar rumah atau bahkan hanya didalam rumah saja.Pada penelitian ini peneliti hanya fokus pada sistem pendeteksi keberadaan lansia pada sebuah ruangan.

\section{c. Arduino Mega 2560}

Model Arduino Mega 2560 berdasarkan mikrokontroller Atmega 2560 yang sangat powerful, memilki frekuensi clock $16 \mathrm{MHz}$. Salah satu keunggulan terbesar model Mega 2560 adalah ukuran flash memory yang mencapai $256 \mathrm{~KB}$, delapan kali lebih besar dari ruang memori Arduino Uno, sehingga model Arduino Mega 2560 menjadi platform target proyek perangkat lunak yang kompleks.

\section{d. Node Sensor}

Prinsip kerja dari node sensor karpet adalah sama dengan cara kerja keypad. Ketika sensor node tersebut tertekan maka akan terkirim data berupa logika 0 atau 1 sesuai dengan kondisi input dari sensor. Jika input diberi tegangan 4,5-5 VDc maka akan menghasilkan output 1 , namun jika input tegangan adalah ground maka akan menghasilkan output 0 . Pada penelitian ini telah dirancang sejumlah sensor keypad yang dirakit dan dipasang pada bagian bawah karpet, hal ini bertujuan untuk melindungi keypad dari pijakan kaki serta berfungsi sebagai input data pada saat lansia sedang menginjak karpet.

Untuk merancang sensor node menggunakan keypad dibutuhkan beberapa komponen seperti keypad, resistor dan kabel penghubung. Semua komponen tersebut dirakit sedemikian rupa sehingga dapat saling terhubung dan terpasang pada karpet. Input pada sistem ini adalah berupa logika 0 yaitu berupa tegangan ground. Ketika keypad tertekan maka akan menghantarkan arus listrik ground yang bernilai input 0 ke Arduino mega. Berikut adalah model perancangan dari sensor node yang dibangun. 


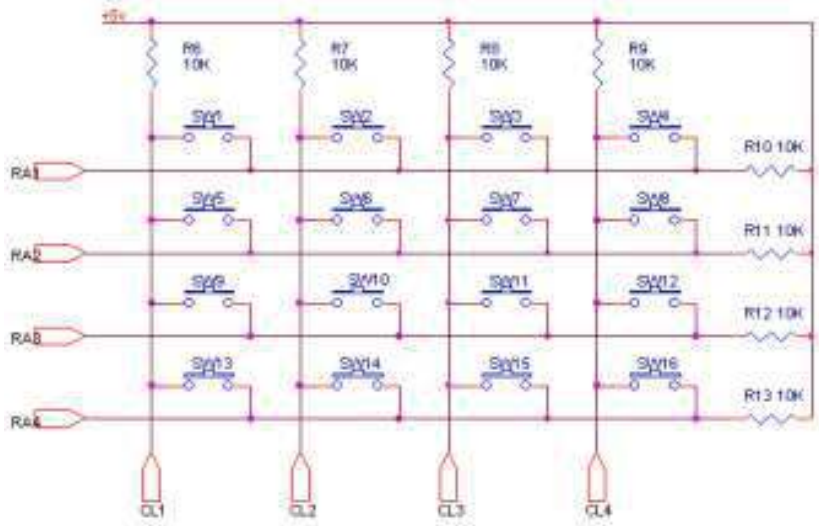

Gambar 1. Rangkaian sensor node (keypad)[4]

\section{e. Rancangan Karpet}

Pada penelitian ini telah dirancang sebuah model karpet yang digunakan untuk mendeteksi aktivitas lansia pada saat berdiri/berjalan, duduk dan berbaring. Pada karpet yang dirancang adalah berukuran $120 \times 240 \mathrm{~cm}$, dimana pada bagian bawah karpet tersebut dirakit sejumlah node sensor keypad yang berjumlah 30 buah titik yang digunakan untuk mengirim data ke Arduino mega. Berikut adalah gambar perancangan karpet yang dibangun berdasarkan output node sensor pada saat lansia sedang berdiri/berjalan, duduk atau berbaring.

Pada gambar 4 merupakan rancangan data output yang diharapkan pada saat lansia sedang berdiri/berjalan, duduk atau berbaring. Titik node warna merah menandakan bahwa node sensor tertekan dan titik node warna hitam menandakan node sensor tidak tertekan.

Gambar 4(a) merupakan kondisi node karpet pada saat lansia sedang berdiri atau berjalan. Jika jumlah node yang tertekan adalah antara 2 hingga 4 node maka lansia sedang berdiri atau berjalan. Gambar 4(b) merupakan kondisi node karpet pada saat lansia sedang duduk. Jika jumlah node yang tertekan adalah antara 5 hingga 8 node maka lansia sedang duduk. Gambar 4(c) merupakan kondisi node karpet pada saat lansia sedang berbaring. Jika jumlah node yang tertekan adalah diatas 9 node maka lansia sedang berbaring. 


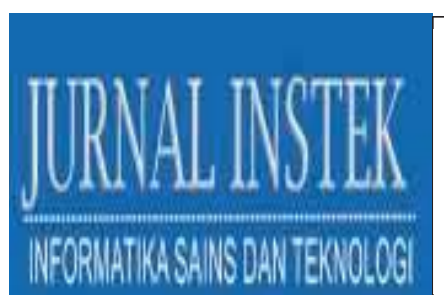

Volume 3 Nomor. 1, April 2018

P-ISSN : 2541-1179, E-ISSN : 2581-1711

Ojs :http://journal.uin-alauddin.ac.id/index.php/instek/index

Email : instek@uin-alauddin.ac.id

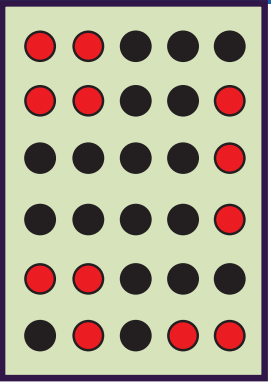

(a) (b)

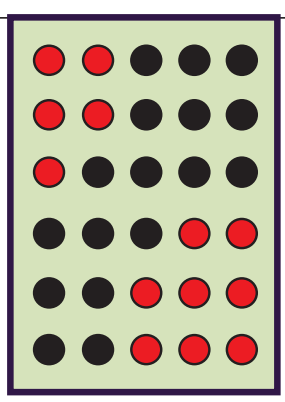

(c)

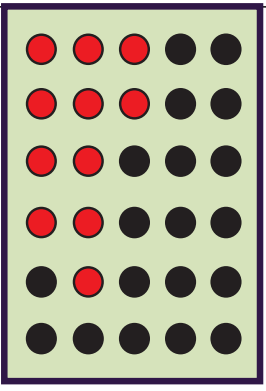

Gambar 2. (a) Kondisi node karpet saat berdiri/berjalan; (b) Kondisi node karpet saat duduk; (c) Kondisi node karpet saat berbaring. Warna merah = tertekan, warna hitam $=$ tidak tertekan.

\section{Hasil Dan Pembahasan}

\section{Hasil}

Dalam penelitian ini algoritma greedy digunakan untuk menentukan kondisi sensor pada saat terinjak atau tertekan dibawah karpet. Setiap satu node sensor mewakili dari satu titik, sehingga dengan menggunakan algoritma akan mendeteksi titik terdekat yang terinjak pada sekitar node sensor.Setiap node sensor saling terhubung antara satu dengan lainnya, dimana jarak dan jumlah node sensor yang terinjak akan menjadi keputusan dari aktivitas lansia. Terdapat beberapa kondisi yang akan dideteksi berdasarkan aktivitas lansia yaitu pada saat lansia sedang berdiri, berjalan, duduk dan berbaring. Alasan mengapa penulis menggunakan algoritma greedy adalah karena prosesnya yang rakus dan cepat dalam mengambil keputusan.

Untuk menyusun algoritma ini dibutuhkan sebuah rancangan flowchart yang akan mejadi acuan dalam pembuatan program sehingga apa yang diharapkan dari sistem dapat berjalan dengan baik. Berikut adalah penerapan flowchart yang digunakan pada algoritma greedy untuk menentukan titik-titik node sensor yang tertekan pada karpet. 


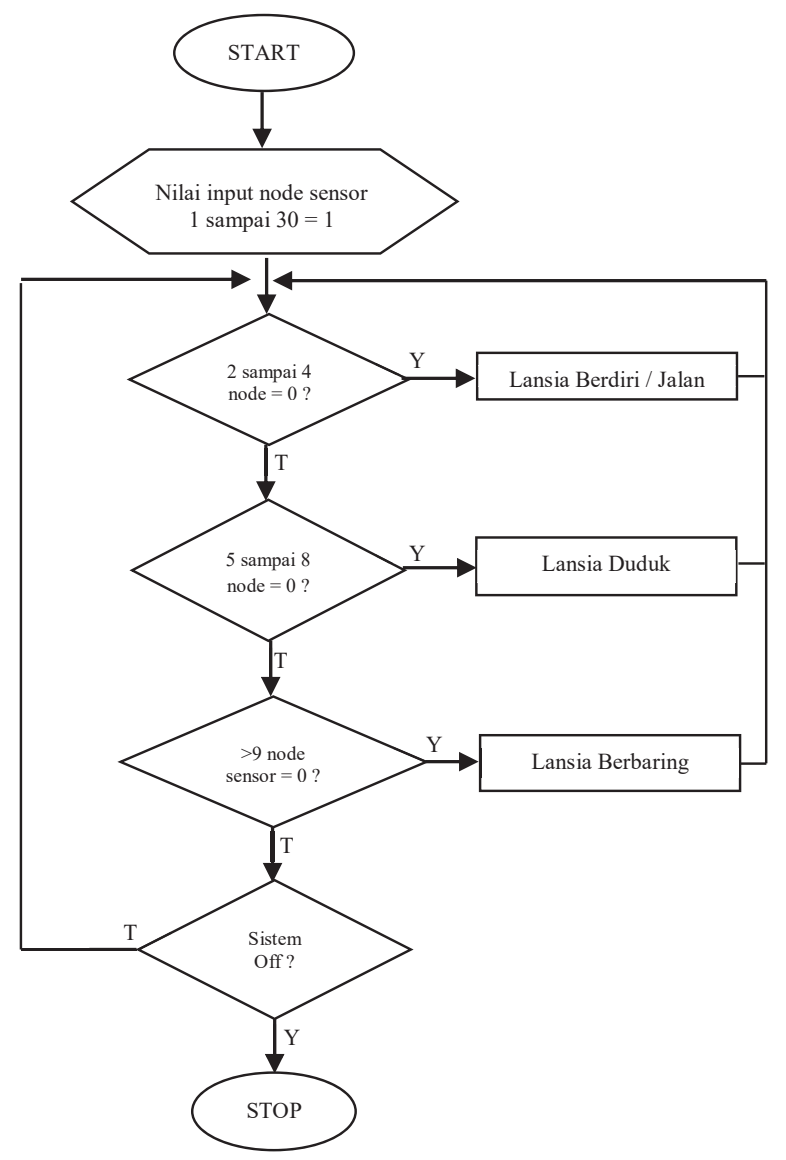

Gambar 3. Flowchart algoritma pembacaan node sensor pada karpet

Berikut adalah penjelasan dari flowchart program yang telah dibangun:

a. Start, berfungsi untuk memulai sistem.

b. Nilai input node sensor 1 sampai $30=1$. Pada program nilai awal pada input keypad adalah 1. Nilai tegangan yang dimasukkan ke keypad adalah 0, jika keypad pada karpet tertekan maka sistem akan membaca bahwa input ke mikrokontroler adalah bernilai 0 .

c. 2 sampai 4 node $=0$ ? Jika jumlah node sensor yang tertekan pada karpet antara 2 hingga 4, maka lansia dalam keadaan berdiri atau berjalan.

d. 5 sampai 8 node $=0$ ? Jika jumlah node sensor yang tertekan pada karpet antara 5 hingga 8 , maka lansia dalam keadaan duduk. 
Volume 3 Nomor. 1, April 2018

P-ISSN : 2541-1179, E-ISSN : 2581-1711

Ojs :http://journal.uin-alauddin.ac.id/index.php/instek/index

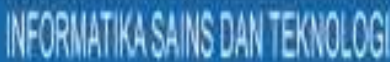

Email : instek@uin-alauddin.ac.id

e. $>9$ node sensor $=0$ ? Jika jumlah node sensor yang tertekan pada karpet lebih dari 9, maka lansia dalam keadaan berbaring.

f. Lansia berdiri/berjalan, merupakan output dari sistem bahwa lansia sedang berdiri atau berjalan.

g. Lansia duduk, merupakan output dari sistem bahwa lansia sedang duduk.

h. Lansia berbaring, merupakan output dari sistem bahwa lansia sedang berbaring.

i. Sistem off? Merupakan kondisi jika sistem dimatikan maka seluruh proses akan berhenti, namun jika tidak maka proses looping akan terus berjalan untuk membaca input pada node sensor.

j. Stop, program dan sistem berhenti.

\section{Pembahasan}

Pembahasan dari hasil dari penelitian ini adalah bagaimana merancang sebuah karpet yang dapat mendeteksi aktivitas lansia pada saat berdiri/berjalan, duduk atau berbaring. Pada karpet tersebut dirancang sedemikian rupa berupa node sensor yang terbuat dari keypad yang berfungsi untuk mendeteksi pijakan pada saat lansia beraktivitas diatas karpet. Ukuran karpet yang telah dirancang adalah berukuran 120 x $240 \mathrm{~cm}$. Selain rancangan karpet penelitian ini juga fokus pada penerapan algoritma greedy sebagai perangkat lunaknya, dimana algoritma ini sangat menentukan dari keputusan sistem yang telah dibangun dalam mendeteksi aktivitas lansia. Berikut adalah gambar karpet hasil penelitian.

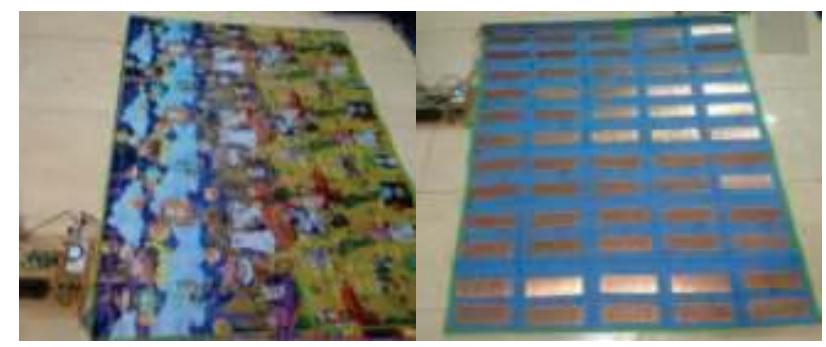

(a)

(b)

Gambar 4. Hasil perancangan karpet. (a) Tampak atas; (b) Tampak bawah. 


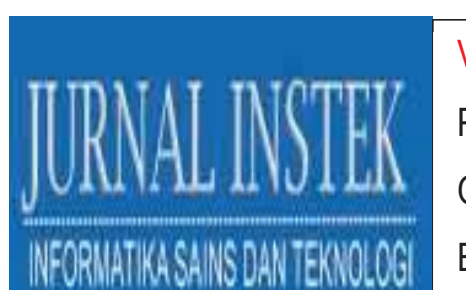

Volume 3 Nomor. 1, April 2018

P-ISSN : 2541-1179, E-ISSN : 2581-1711

Ojs :http://journal.uin-alauddin.ac.id/index.php/instek/index

Email : instek@uin-alauddin.ac.id

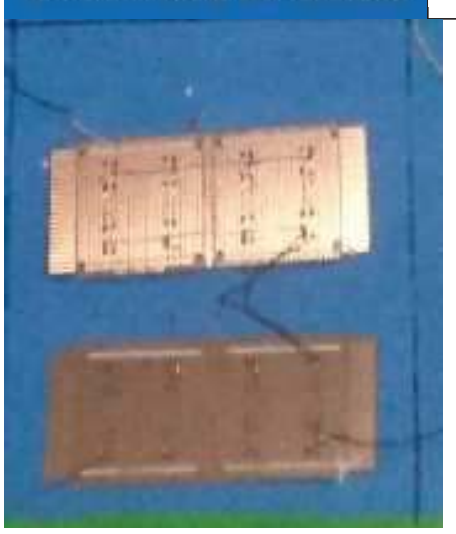

(a)

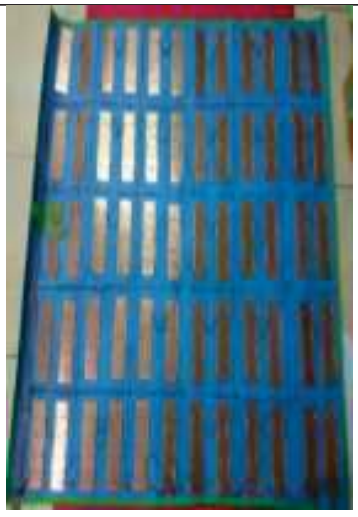

(b)

Gambar 5. Node sensor. (a) 30 Node sensor; (b) 1 Node sensor

Input data dari karpet kemudian akan terhubung ke Arduino Mega dan di olah menggunakan algoritma greedy. Terdapat 30 pin yang digunakan pada Arduino mega untuk membaca input data dari node sensor. Berikut adalah tabel penggunaan pin pada Arduino mega yang terhubung ke node sensor.

Tabel 1. Penggunaan pin Arduino mega yang terhubung ke Node sensor keypad.

\begin{tabular}{|c|c|c|}
\hline $\begin{array}{c}\text { Pin Arduino } \\
\text { Mega }\end{array}$ & $\begin{array}{l}\text { Kondisi Node } \\
\text { Sensor }\end{array}$ & Hasil output \\
\hline \multirow{2}{*}{$\begin{array}{l}2-8,14-21,25, \\
27,29,31,33, \\
35,37,37,39, \\
41,43,45,47, \\
49,51,53\end{array}$} & $\begin{array}{c}0 \text { Node sensor } \\
\text { tertekan }\end{array}$ & Tidak ada aktivitas lansia \\
\hline & $\begin{array}{l}\text { Node sensor } \\
\text { tertekan }\end{array}$ & Aktivitas lansia tidak terdeteksi \\
\hline \multirow{3}{*}{$\begin{array}{l}2-8,14-21,25, \\
27,29,31,33, \\
35,37,37,39 \\
41,43,45,47 \\
49,51,53\end{array}$} & $\begin{array}{l}2 \text { Node sensor } \\
\text { tertekan }\end{array}$ & Lansia sedang berjalan / berdiri \\
\hline & $\begin{array}{c}3 \text { Node sensor } \\
\text { tertekan }\end{array}$ & Lansia sedang berjalan / berdiri \\
\hline & $\begin{array}{l}4 \text { Node sensor } \\
\text { tertekan }\end{array}$ & Lansia sedang berjalan / berdiri \\
\hline \multirow{3}{*}{$\begin{array}{l}2-8,14-21,25, \\
27,29,31,33, \\
35,37,37,39, \\
41,43,45,47, \\
49,51,53\end{array}$} & $\begin{array}{c}5 \text { Node sensor } \\
\text { tertekan }\end{array}$ & Lansia sedang duduk \\
\hline & $\begin{array}{l}6 \text { Node sensor } \\
\text { tertekan }\end{array}$ & Lansia sedang duduk \\
\hline & $\begin{array}{l}7 \text { Node sensor } \\
\text { tertekan }\end{array}$ & Lansia sedang duduk \\
\hline
\end{tabular}




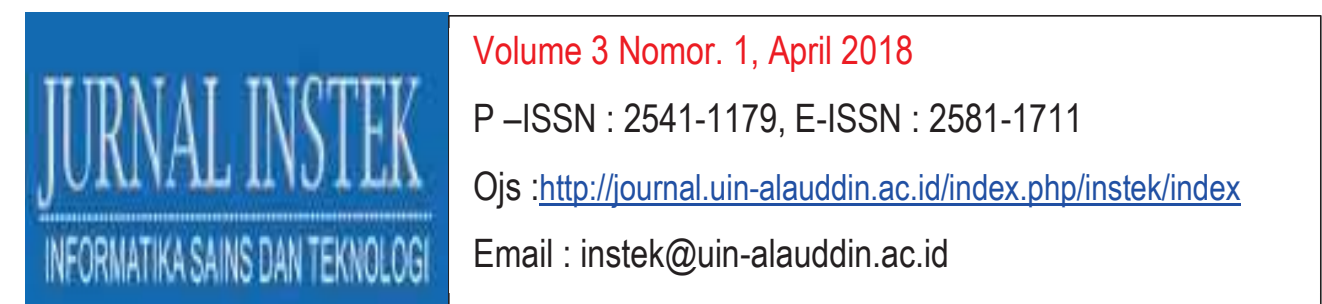

\begin{tabular}{|l|c|l|}
\hline & $\begin{array}{c}8 \text { Node sensor } \\
\text { tertekan }\end{array}$ & Lansia sedang duduk \\
\hline $2-8,14-21,25$, & $\begin{array}{c}\text { Node sensor } \\
\text { tertekan }\end{array}$ & Lansia sedang berbaring / tidur \\
$27,29,31,33$, \\
$35,37,37,39$, \\
\cline { 2 - 3 } $41,43,45,47$, & $\begin{array}{c}\text { 10 Node sensor } \\
\text { tertekan }\end{array}$ & Lansia sedang berbaring / tidur \\
\cline { 2 - 4 } & $\begin{array}{c}\text { 11 Node sensor } \\
\text { tertekan }\end{array}$ & Lansia sedang berbaring / tidur \\
\cline { 2 - 4 } & $\begin{array}{c}\text { 12 Node sensor } \\
\text { tertekan }\end{array}$ & Lansia sedang berbaring / tidur \\
\hline
\end{tabular}

Pada tabel terlihat bahwa jika Arduino tidak mendeteksi kondisi sensor tertekan maka tidak ada aktivitas lansia diatas karpet. Jika sistem mendeteksi hanya satu node sensor yang tertekan maka aktivitas lansia tidak terdeteksi. Jika sistem mendeteksi antara 2 sampai 4 node sensor yang tertekan maka lansia sedang berjalan atau berdiri. Jika node sensor yang terdeteksi antara 5 sampai 8 titik maka lansia sedang duduk dan jika node sensor yang terdeteksi adalah lebih dari 9 titik maka aktivitas lansia dalam keadaan tidur atau berbaring diatas karpet.

Untuk menguji perangkat lunak algortima greedy yang telah dibangun, maka berikut adalah hasil pengambilan data dapa saat lansia sedang berdiri, duduk atau berbaring. Pada outout program terdapat tulisan "lantai" yang menandakan bahwa node sensor tertekan.
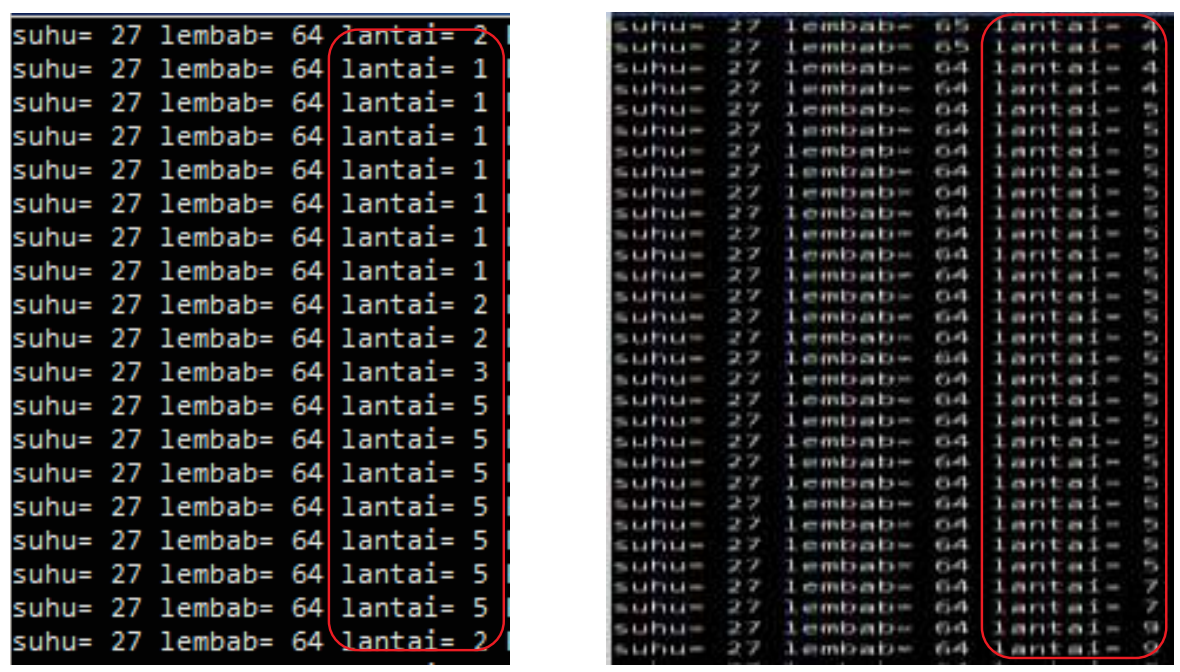

Gambar 6. Proses pengambilan data (lantai) untuk mendeteksi

aktivitas lansia pada karpet. 
Volume 3 Nomor. 1, April 2018

P-ISSN : 2541-1179, E-ISSN : 2581-1711

Ojs :http://journal.uin-alauddin.ac.id/index.php/instek/index

Email : instek@uin-alauddin.ac.id

\section{Penutup}

\section{Kesimpulan}

Hasil dari penelitian ini adalah Algoritma Greedy dapat digunakan untuk menentukan aktivitas lansia ketika sedang berdiri/berjalan, duduk dan berbaring. Karpet yang dirancang berukuran $120 \times 240 \mathrm{~cm}$ yang mempunyai 30 buah node sensor dan berfungsi untuk mendeteksi aktivitas lansia diatas karpet. Jika node sensor yang tertekan antara 2 sampai 4 maka lansia sedang berdiri/berjalan, jika 5 sampai 8 node tertekan maka lansia sedang duduk dan jika yang tertekan lebih dari 9 node maka lansia sedang berbaring. Input dari node sensor tersebut akan diolah oleh Arduino mega kemudian outputnya adalah berupa nilai yang dapat diambil untuk bisa dikembangkan pada penelitian berikutnya.

Penelitian yang akan dilakukan selanjutnya adalah hasil dari data tersebut kemudian diolah di Web agar dapat diakses secara online dan mobile, sehingga memudahkan penjaga lansia dalam memonitoring aktvitas lansia secara online dan realtime.

\section{Daftar Pustaka}

Pujianti Wahyuningsih. "Rancang Bangun Sistem Deteksi Aktivitas Lansia Berbasis Arduino Mega",JURNAL IT: Media Informasi STMIK Handayani, Volume 8 No 2, Agustus 2017.

Abdul Jalil, Pujianti Wahyuningsih "Penerapan Algoritma Greedy Pada Sistem Penukaran Nominal Mata Uang Rupiah"Konferensi Nasional Ilmu Komputer (KONIK) 2014, APTIKOM. ISSN: 2338-2899.

Soleh, Andi Susilo. "Desain dan implementasi smart home sistem pengendali lampu rumah berbasis arduino mega". Seminar Riset Teknologi Informasi (SRITI) tahun 2016.

http://www.electroons.com/8051/electroons/images/keypad.jpg. [online], diakses pukul 18.20 pada tanggal 7 Februari 2018. 